\title{
ROBOTKAR INVERZ KINEMATIKAI FELADATÁNAK MEGOLDÁSA „KVÁZIDIFFERENCIÁLIS” FIXPONT TRANSZFORMÁCIÓS MÓDSZERREL
}

\section{SOLUTION OF THE INVERSE KINEMATIC TASK OF A ROBOT-ARM BASED ON „QUASI-DIFFERENTIAL” FIXED- POINT TRANSFORMATION METHOD}

\author{
Faitli Tamás ${ }^{1}$, Tar József ${ }^{2}$ \\ ${ }^{1}$ Óbudai Egyetem, Bánki Donát Gépész és Biztonságtechnikai Mérnöki Kar, 1034 \\ Magyarország, Budapest, Bécsi út 96/B; Tel. +36-1-666-5300, faitlit@gmail.com \\ ${ }^{2}$ Óbudai Egyetem, Bejczy Antal iRobottechnikai Központ, 1034 Magyarország, Bu- \\ dapest, Bécsi út 96/B; Tel. +36-1-666-5543, tar.jozsef@nik.uni-obuda.hu
}

\begin{abstract}
While the forward kinematic task of robots can be solved easily through homogenous transformation matrices, the inverse kinematic task leads to difficulties as the construction of the system gets more complex. In this paper, a solution has been worked out for a three Degree-of-Freedom robot-arm based on recent researches, by the use of a novel, fixed-point transformation based technique.
\end{abstract}

Keywords: robot-arm, inverse kinematics, fixed-point theorem, „quasi-differential” solution.

\section{Összefoglalás}

Míg egy robotkar direkt kinematikai feladata általában homogén transzformációs mátrixok segítségével egyszerüen megoldható, addig az inverz kinematikai feladat a rendszer felépítésétől függően rendkívül bonyolulttá válhat. Jelen dolgozatban egy nemrégi kutatásra alapozva, fixpont transzformáción alapuló közelítő numerikus megoldás került kidolgozásra egy három szabadsági fokú robotkar inverz kinematikai feladatának megoldására.

Kulcsszavak: robotkar, inverz kinematika, fixpont, „kvázidifferenciális” megoldás.

\section{Bevezetés}

Nyílt láncú robotkarok inverz kinematikai feladata, vagyis, hogy a kar végpontjának egy adott helyzetét milyen csuklóállásokkal tudjuk elérni sokszor egy rendkívül bonyolult feladat. Egy redundáns, néhány szabadsági fokú rendszernél is végtelen számú ,„pózban” elérhető a végpontnak egy kívánt pozíciója. A hagyományos megközelítések ezen feladat megoldására többnyire magukba foglalnak egy mátrix invertáló műveletet, ami a robot kinematikailag szinguláris pontjainál kiszámíthatatlan. A mozgás során, ez hirtelen „rángásokat” eredményezhet, ami egyaránt magára és a környezetére is veszélyes. [1]-ben, egy új eljárás került kidolgozásra, ami a feladatot egy fixpont feladattá alakítja, ami nem tartalmaz mátrix invertáló műveletet, így elkerülhető a szinguláris pontoknál, vagy azok közelében, az ún. rosszul kondicionált esetekben adódó probléma. 


\subsection{A „Kvázidifferenciális” fixpont transzformációs módszer mükö- déséről röviden}

Vegyük $q \in \mathbb{R}^{n}, n \in \mathbb{N}$ tömböt, ami egy n szabadsági fokú nyílt kinematikai lánc csuklóinak koordinátáit tartalmazza, valamint $x \in \mathbb{R}^{m}, m \in \mathbb{N}$ tömböt, ami a robotkar egyes pontjainak Descartes mühelykoordinátáit foglalja magába. Továbbá vegyük $s \in\left[s_{i}, s_{f}\right] \subset \mathbb{R}$ paramétert, ami vagy egybeesik magával az idővel, vagy annak függvénye, így, $x(s)$ a nominális mozgást írja le.

Tegyük fel, hogy adott egy $f: \mathbb{R}^{n} \rightarrow \mathbb{R}^{n}$, mint $x=f(q)$ nemlineáris, differenciálható valós függvény, ahol a feladat az adott $x$ értékhez a $q$ változó megtalálása. Ez [2]ben a következőképp lett átalakítva egy fixpont problémára. Vegyünk egy $F(\xi): \mathbb{R} \rightarrow \mathbb{R}$ valós differenciálható függvényt, aminek van egy "attraktív fixpontja" $F\left(\xi_{\star}\right)=\xi_{\star}$. Az $F(\xi)$ függvény használatával egy sorozat alkotható az ismétlődő jelekből:

$$
\begin{aligned}
& q_{s, i+1}= {\left[F\left(A\left\|f\left(q_{s, i}\right)-x\right\|+\xi_{\star}\right)-\right.} \\
&\left.\xi_{\star}\right] \frac{f\left(q_{s, i}\right)-x}{\left\|f\left(q_{s, i}\right)-x\right\|}+q_{s, i}
\end{aligned}
$$

amiben a normált kifejezés Frobenius formulával számítható, az $A \in \mathbb{R}$ pedig egy konstans paraméter. Amennyiben egy adott $k$ iteráció során, ahol $q_{s, k}=q_{\star}$ értéke kielégíti az $x=f\left(q_{\star}\right)$ feltételt, az (1) egyenlet $q_{s, k+1}=q_{s, k}$ egyenletbe torkollik, amiből egyértelmüen látszik, hogy $q_{\star}$ megoldás egyben a függvény fixpontja is lesz. Amennyiben (1) konvergenciája garantálható, egy aktuálisan elérni kívánt $x$ (s) betáplálásával az algoritmus néhány iteráció után megközelíti a függvény fixpontját, vagyis $q_{s, i}$ a probléma megoldásába fog tartani, ami alapján megkapjuk a szükséges $q_{s}$ csuklóállásokat.

A konvergencia eléréséhez fontos paraméter az $A$ konstans érték, melynek több- nyire egy kis, jól megválasztott előjelü érték szükségeltetik. A müködéshez még fontos megemlíteni, hogy a módszer feltételezi, hogy a rákövetkező $s+1$ időpillanatban az (1) egyenletben $q_{s, i}$ a fixpont közelében tartózkodik, ami belátható abból, hogy kezdetben ismerjük a robot helyzetét, utána pedig kis lépésekben haladunk tovább.

A módszer továbbá egy közelítő Jacobi mátrix használatát javasolja a konvergencia garantálásához, ami mellesleg elkerüli azon eseteket is, mikor a konstrukció miatt egy robotkar Jacobi mátrixa nem négyzetes alakot vesz fel. A javaslat szerint $x$ helyett egy módosított $\tilde{x} \equiv J^{T}(q) x=J^{T} f(q)$ kifejezés alkalmazása szükséges.

\section{Implementáció}

A módszer implementálása és eredményeinek vizsgálata jelen dolgozatban szimulációs úton történt, elérhetősége, és egyszerüsége miatt.

\subsection{A vizsgált rendszer}

A vizsgált robotkar modellje az 1. ábrán látható. A robotkar részletesebb leírása és annak levezetése [3]-ban található.

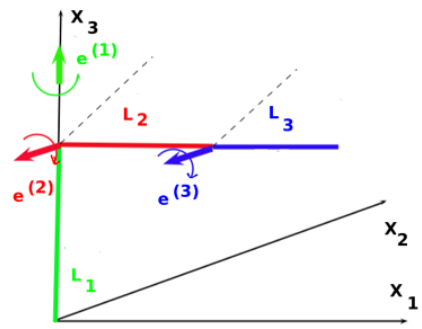

1. ábra. A vizsgált robotkar kinematikai modellje az „alappozícióban”

Amennyiben a 3. karrész végpontja pályájának követése a cél, az implementáláshoz elegendő a végpont Descarteskoordinátáinak ismerete. Ezeket a direkt kinematika alapján egyszerüen megkaphatjuk. (Az áttekinthetőség kedvéért vezessük be a $c_{i} \equiv \cos \left(q_{i}\right)$, valamint a $c_{i j} \equiv$ 
$\cos \left(q_{i}+q_{j}\right)$ jelöléseket, valamint hasonló eljárással az $s_{i}, s_{i j}$ szinusz változatukat.)

$$
\left(\begin{array}{l}
x_{3 v} \\
y_{3 v} \\
z_{3 v}
\end{array}\right)=\left(\begin{array}{c}
L_{3} c_{1} c_{23}+c_{1} c_{2} L_{2} \\
L_{3} s_{1} c_{23}+s_{1} c_{2} L_{2} \\
-S_{23} L_{3}-s_{2} L_{2}+L_{1}
\end{array}\right)
$$

(2)-ben a megfelelő tagok parciális deriválása után megkapjuk a robot Jacobi mátrixát, vagyis a $J=$

$\left(\begin{array}{ccc}-L_{3} c_{23} S_{1}-L_{2} c_{2} s_{1} & -L_{3} c_{1} s_{23}-L_{2} c_{1} s_{2} & -L_{3} c_{1} s_{23} \\ L_{3} c_{1} c_{23}+c_{1} c_{2} L_{2} & -L_{3} s_{1} s_{23}-s_{1} s_{2} L_{2} & -L_{3} s_{1} s_{23} \\ 0 & -L_{3} c_{23}-L_{2} c_{2} & -L_{3} c_{23}\end{array}\right)$

\subsection{Szimuláció}

A szimuláció az fmtu_simulation.jl „julia” programnyelvben íródott szkript segítségével lett végrehajtva.

$\mathrm{Az}$ (1)-ben szereplö $F(\xi)$ függvény a szimulációban az $F(\xi)=\frac{\xi}{2}+D$ függvénynyel valósult meg. A további paramétereket az 1. táblázat tartalmazza.

1. táblázat. A szimuláció paraméterei

\begin{tabular}{|c|c|}
\hline 1. szegmens hossza $\mathrm{L}_{1}[\mathrm{~m}]$ & 1.5 \\
\hline 2. szegmens hossza $\mathrm{L}_{2}[\mathrm{~m}]$ & 0.8 \\
\hline 3. szegmens hossza $\mathrm{L}_{3}[\mathrm{~m}]$ & 0.5 \\
\hline$A$ & -1.0 \\
\hline$D$ & 0.3 \\
\hline
\end{tabular}

A nominális pályák egyszerü szinuszfüggvényekkel lettek generálva, vagyis a robotkar a rendelkezésre álló munkatérben folyamatosan pásztázik. A direkt kinematika segítségével egy előzetes ciklusban elöször tárolásra került ez a generált „nominális” pálya, amit aztán bevezetünk a fentebb bemutatott algoritmusba, mint elérni kívánt pálya, és hagyjuk, hogy az megállapítsa magától a szükséges csuklóállásokat. Ezek szintén tárolásra kerülnek, amit a végén ábrázol a program.

\subsection{Eredmények}

Az szimuláció eredményei a következő ábrákon láthatók.

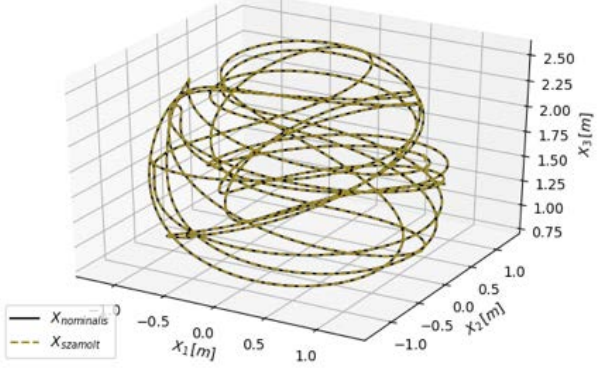

2. ábra. A nominális és a számolt Descarteskoordináták 3D-s ábrázolása

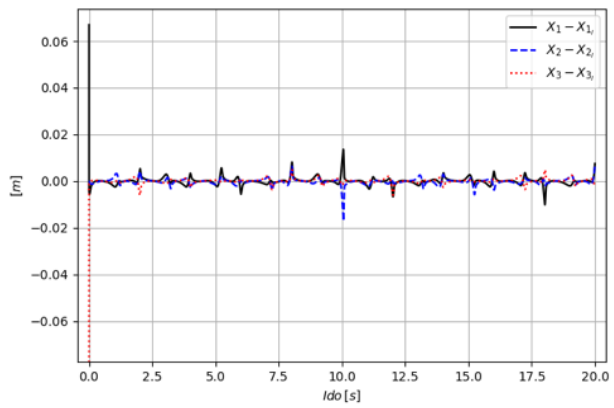

3. ábra. Trajektóriakövetési hiba

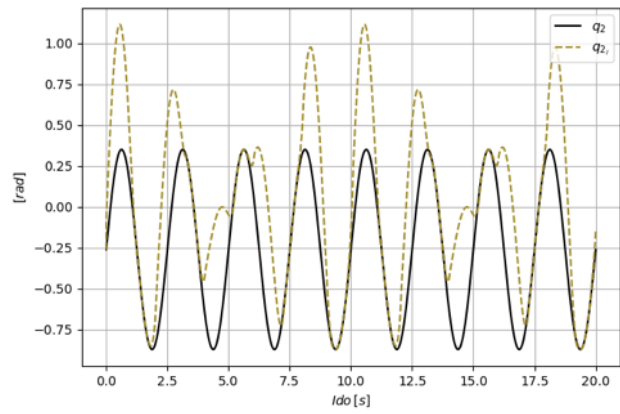

4. ábra. A nominális és a számolt $q_{2}$ csuklókoordináták

Jól látható, hogy a Descartes mühelykoordináták követése meglehetősen pontos, miközben a csuklókoordináták helyenként eltérnek az eredeti, nominális értékektől. Ez annak felel meg, hogy a követett pálya egyes részei különböző kar-konfigurációkkal is elérhetők: a megoldásként adott 
mozgás más kar-konfigurációnak felel meg, mint az a mozgás, amivel a követendő pályát létrehoztuk. A kétféle út közti szétválás a szinguláris pontokban lehetséges.

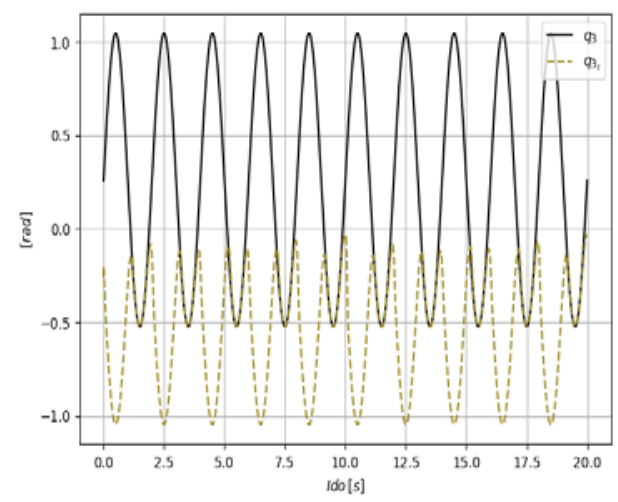

5. ábra. A nominális és a számolt $q_{3}$ csuklókoordináták

Érdemes megnézni továbbá a Jacobi mátrix sajátértékeit a szimuláció során. Ez minimális bővítéssel a programkódban már hasonlóan ábrázolható.

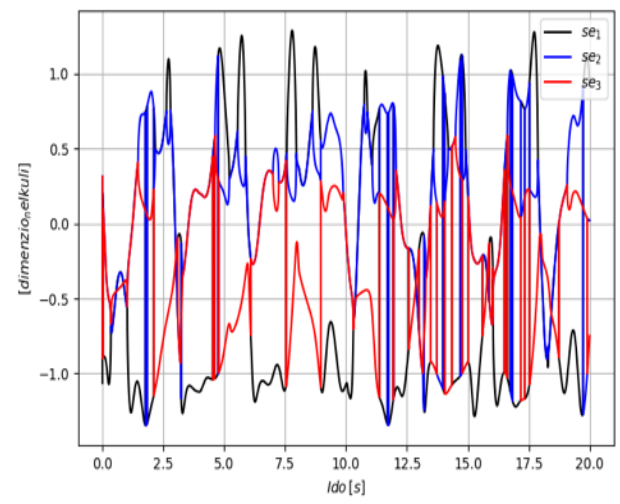

6. ábra. A Jacobi mátrix sajátértékeinek valós része

Látható, hogy több pontban is 0 értéket vesz fel a Jacobi mátrix valamely sajátértéke, azaz a robotkar a mozgás során többször is áthalad kinematikailag szinguláris pontokon.

\section{Következtetések}

A dolgozat tárgyát képző módszer egyszerüen implementálható, annak paraméterei szimulációs úton könnyedén beállíthatók, ami végül meglehetősen jó pályakövetést eredményez még a szinguláris pontokban és azok környezetében is.

Amennyiben a számolt csuklókoordinátákon pontosítani szeretnénk, az $x$ tömböt, valamint annak alapján a Jacobi mátrixot kibővíthetjük a robotkar további pontjaival, így elösegíthetjük, hogy az automatikusan választott megoldás közelebb legyen az általunk kívánt megoldáshoz.

\section{Köszönetnyílvánítás}

A jelen közlemény az Emberi Erőforrások Minisztériuma ÚNKP-17-1-I kódszámú Új Nemzeti Kiválósági Programjának, valamint az NTP-HHTDK-17-0047 kódszámú programjának támogatásával készült.

\section{Szakirodalmi hivatkozások}

[1] B. Csanádi; J.K. Tar; J.F. Bitó: Matrix inversion-free quasi-differential approach in solving the inverse kinematic task. In Proc. of the $17^{\text {th }}$ IEEE International Symposium on Computational Intelligence and Informatics (CINTI 2016), 17-19 November 2016, Budapest, Hungary, 61-66.

[2] A. Dineva; J.K. Tar; A. Várkonyi-Kóczy; V. Piuri: Adaptive control of underactuated mechanical systems using improved "Sigmoid Generated Fixed Point Transformation" and scheduling strategy. In Proc. of the $14^{\text {th }}$ IEEE International Symposium on Applied Machine Intelligence and Informatics, January 21-23, 2016, Herl'any, Slovakia, 2016, 193-197.

[3] T. Faitli: Robotkar dinamikai szabályozásának szimulációs összehasonlító vizsgálata "Fixpont Transzformációs Adaptív" és "Fixpont Transzformáción Alapuló Modell Referenciás Adaptív (MRAC)" szabályozóval. TDK dolgozat, ÓE-BGK Kari TDK Konferencia, 2017. nov. 15. 